Maciejewski, M., \& Wach, K. (2019). What determines export structure in the EU countries? The use of gravity model in international trade based on the panel data for the years 1995-2015. Journal of International Studies, 12(1), 151-167. doi:10.14254/2071-8330.2019/12-1/10

\title{
What determines export structure in the EU countries? The use of gravity model in international trade based on the panel data for the years 1995-2015
}

\author{
Marek Maciejewski \\ Department of International Trade, Cracow University of Economics \\ Poland \\ maciejem@uek.krakow.pl \\ Krzysztof Wach \\ Department of International Trade, Cracow University of Economics \\ Poland \\ wachk@uek.krakow.pl
}

Abstract. The aim of this article is to demonstrate the differences in the intensity of production factors' use in the export of the European Union countries, which cannot be explained only by the resources available at the disposal of these countries. The paper is an empirical analysis of the general and bilateral trade of the EU countries. The article uses statistical data for comparative analysis of the export structure and further construction of the gravity model. The line of reasoning consists of two essential elements. First, conclusions are drawn based on literature analysis. The main empirical part of the article is based on quantitative analysis (the gravity model using secondary data). UNCTAD was used as the data source of statistical data. Commercial cooperation attractiveness in the EU is a key factor in constructing the gravity model of foreign trade. The attractiveness can be expressed as the size and level of development of economic partners, geographical distance and the common border. Nevertheless, new variables such as memberships in the EU and the EMU were added. The resources of production factors have no direct impact on the export structure. The chosen direction of economic cooperation is crucial.

Keywords: export, international trade, commodity structure, production factors, gravity model.

JEL Classification: F14 


\section{INTRODUCTION}

There are four main neoclassical trade theories, namely, the factor price equalization proposition (Samuelson, 1948; 1949), the Stolper-Samuelson proposition (Stopler \& Samuelson, 1941), the Rybczynski proposition (Rybczynski, 1955) and the Heckscher-Ohlin proposition (Ohlin, 1933). According to the Heckscher-Ohlin factor abundance theory, each country should specialize in the manufacturing and exporting of those goods the production of which requires more intensive use of manufacturing facilities (van Marrewijk, 2017). This part of the Heckscher-Ohlin model is commonly known as the H-O theorem. It requires fulfilling a number of assumptions, such as identical buyer preferences and similar technology of manufacturing in each country, no trade restrictions and mobility of domestic production factors on the international scale (Marrewijk, 2017). The second part of the model derived from the Heckscher-Ohlin analysis, assuming equalization of prices for the factors of production in free trade, as defined by The Heckscher-Ohlin-Samuelson theorem (H-O-S theorem). In the assumption of the theorem, the specialization in the manufacturing of products based on abundant resources will lead to increased prices and also to decreases prices for resources from which production has been withdrawn for the benefit of imports. Therefore, despite the lack of mobility of production factors, their prices will be offset by international trade. It is a substitute for the mobility of production factors because export of products based on the use of a particular factor generates, indirectly, the export of this factor to the market of a trading partner (Morawczyński \& Wach, 2004). Attempts to verify empirically this Heckscher-Ohlin's assertion usually failed to confirm its validity (Cieślik, Michałek, \& Mycielski, 2012). This was mainly due to the assumptions being difficult to meet, including the mobility of production factors, which, on the one hand, assumes no cost of shifting resources within a country or a firm, and on the other, does not take into account the excesses of this mobility outside the country. The theory also failed to take into account the development of intra-industry trade, which was mainly between highly developed countries with similar equipment and production factors based on advantages gained through the economies of scale (Cieślik, 2005). Sources of business dominance were perceived solely in their environment, disregarding the issues of improved productivity through technology transfer, product quality improvement, or production organization (Yassar \& Morisson Paul, 2008).

The article deals with the issue of the intensity of the use of production factors in the export structure of European Union countries to the EU market. The purpose of the study is to identify the basic empirical factors determining the export volume and structure in the countries of the European Union. It will be also possible to demonstrate that the resources of the production actors are not directly reflected in the structure of goods. This was done by analyzing the structure of individual countries' exports to the EU market, examining bilateral trade within the EU with elements of comparative analysis, and by using the gravity model of international trade for product groups that were isolated due to the intensity of use of the manufacturing factors. "The gravity model has been extensively used in international trade research for the last 40 years because of its considerable empirical robustness and explanatory power" (Kepaptsoglou, Karlaftis, \& Tramboulas, 2010).

This article contributes to the literature in four aspects. First, many authors, such as van Bergeijk and Brakman (2014) have noticed the comeback of the gravity model in empirical studies of international trade and foreign direct investment. And this article is an attempt to use the recent data (1995-2015), and what is more the data for new member states of the European Union (EU). Second, we extended the traditional gravity model of new variables such as the membership in the EU and in the European Monetary Union (EMU), as well as having a common border between countries. The relative difference in the value of GDP between countries was applied as the augmented variable. Third, we use a gravity model not to use the trade volume only, but to demonstrate the differences in the intensity of use of production factors in the export 
of the European Union countries, which cannot be explained only by resources at the disposal of these countries (Maciejewski, 2017). Fourth, there are not enough evidence and the trade relations need to be empirically tested using different empirical data and perhaps enabling new discoveries by new attempts and trials (Ambroziak, 2017; Brodzicki \& Kwiatkowski, 2018; Sapkota et al., 2018; Tung, 2018).

\section{LITERATURE REVIEW}

The literature presents two opposite attitudes towards the role of the territorial distance while doing business across borders (Wach, 2015). The role of the distance is still being explored in many countries and by many researchers. Cairncross (2001) notices that nowadays geographical distance seems to be out of place in the age of global markets ("death of distance"), but Ellis (2007) highlights that the empirical evidence suggests otherwise ("distance still matters"). This issue has been researched on recently by numerous economists, geographers and especially by international business researchers (Clark, Dollar \& Micco, 2004; Ghemawat, 2001; Frankel \& Rose, 2002). Basile, Parteka, and Pittiglio (2018) confirm the relevance of spatial network effects in export diversification, especially spatial proximity to large countries accelerates the diversification process. This is why we decided to check the role of distance for the export structure in the European Union countries (EU-28).

The distance is connected with the concept of a gravity model of international trade (Linneman, 1966), which was proposed independently by Tinbergen (1962) and Poyhonen (1963). Elmslie (2018) sees even that the gravity model was invented by Adam Smith in his very early theory. This formula was to explain the bilateral flows among countries taking into account the size of countries and the limiting factor in trade, which reflected the costs of movement between the two countries. This proxy of resistance factor was the geographical distance (Anderson, 1979: 106-116).

Martinez-Zarzoso and Nowak-Lehman (2002) applied the augmented gravity model to assess Mercosur-EU trade and trade potential following the agreements that were reached between both trade blocks. Based on the sample of 20 countries and utilizing panel econometric models containing various relevant variables, captured time-invariant country-specific effects, and dynamic relations. Using such variables as proxy infrastructure quality, income differences and exchange rates, allowed to explain determinants of bilateral trade flows more precisely than utilizing a simple core gravity model.

We analyzed the determinants of the export structure in the EU countries (bi-directionally) using the gravity panel data approach (Baltagi, 2005). In the article as potential independent variables describing the value of exports of particular categories of products, it was decided to formulate research hypotheses, assuming the following:

H1a: The higher GDP, both of the exporting country and of the importing country (as its partner), should, therefore, be conducive to an increase in the value of the trade.

H1b: The higher levels of GDP per capita of both exporting and importing partners foster an increase in the value of the trade.

On one hand, larger economies, with their correspondingly larger production, have the opportunities to appear on foreign markets. On the other hand, larger economies also report higher demand that can be met outside the country. The rising level of economic development (measured by GDP or GDP per capita) results in both production and consumption increase. The production effect, based on the new theory of economic growth, takes into account the qualitative aspect of the production factors and takes into account not only their size but also the productivity that grows as the economy grows. On the other hand, the consumption effect is related to the increase in demand for imported goods as a result of 
increased consumer incomes and changes in the structure of this demand (Johnson, 1959; 1968). This is why we will verify the following hypotheses:

H2a: The lower the relative difference in the value of GDP of entities belonging to the analyzed pair of countries (especially in bigger economies), the larger the volume in trade between these countries.

H2b: Leveling the GDP per capita of trading partners cause the increase of the value of their trade.

The ratio of the relative difference in the GDP of entities belonging to the analyzed pair of countries (DistGDP $P_{i j}$ ), which indicates the increasing diversification of export-import potential of economic partners. Especially with the regard to larger economies (as measured by GDP), the reduction of this difference should be conducive to the creation of trade.

The index was calculated using the formula (Somma, 1994, p. 792):

$$
\operatorname{DistGDP_{ij}}=1+\frac{(w) \ln (w)+(1-w) \ln (1-w)}{\ln (2)}, \text { where } w=\frac{G D P_{i}}{G D P_{i}+G D P_{j}}
$$

This indicator is a standardized measure taking values from the range [0,1], where zero denotes the identical GDP of countries, and the approximation to one is equivalent to the increase in the variation between their GDP.

The value of the indicator of the relative difference in GDP per capita of entities belonging to the analyzed pair of countries (DistGDPpcij) is calculated in the same way as for the difference in GDP mentioned above. The slight differences in GDP per capita of a pair of countries may indicate their similar consumer preferences. Meanwhile, the theory of similarity of preference developed by Linder (1961, p. 94) shows that the country exports primarily goods that already exist in the internal market. It guarantees a profitable production and conducts effective competition with producers of identical or similar goods on foreign markets. This means that the level of GDP per capita of trading partners will be conducive to an increase in the value of their trade.

The larger the geographic distance corresponds to the weakening of the attractiveness of commercial cooperation, mainly due to its costs, represented mainly by transport costs, delivery time, but also cultural differences. As the distance between exporting and importing partners grows, trade intensity should be weakened. Brun et al. (2005) state that the estimated coefficient of distance on the volume of trade is generally found to increase rather than decrease through time using the traditional gravity model of trade. This made us to assume the following hypothesis:

H3: The closer the geographic distance of the exporting and the importing partners, the intensity of trade is higher.

Owning by a pair of countries a common border is conducive to establishing business contacts (Shin \& Serlenga, 2004). Results of research done in various parts of the world confirm that (Felipe \& Kumar 2010; Wach, 2015; Fitzsimons, Hogan \& Neary, 2013). This resulted in the following hypothesis:

H4: Having a common border between the exporting and importing partners stimulate the value of the trade. 
The membership in the integration grouping is an incentive to establish commercial cooperation, especially through trade creation and trade diversion. In the analyzed period of 1995-2015, three EU enlargements took place: in 2004 Malta and Cyprus as well as eight Central and Eastern European countries joined the EU; in 2007 Bulgaria and Romania and finally in 2013 Croatia. Bittmannova (2016) using empirical data shows that "even though the EU membership of both countries affects the exports of one to the other member country positively, there is no evidence of the trade creation effect in 1993, when the Single European Market as such had been created", so in-depth further studies are needed. It made us to verify the following hypothesis:

H5: The membership in the EU as the integration grouping stimulates trade between exporting and importing partners.

The elimination of transaction costs and foreign exchange risk are factors supporting the intensification of trade. The common currency in non-cash transactions was introduced on January 1 , 1999, and in cash form as of January 1, 2002, becoming initially a legal tender in twelve EU countries (out of EU-15). Slovenia entered the monetary union in 2007, Cyprus and Malta in 2008, followed by Slovakia in 2009, Estonia in 2011, Latvia in 2014 and Lithuania in 2015 (currently there are 19 members of the EMU). The positive impact of Euro adoption on trade was recently proved empirically by (MartínezZarzoso \& Johannsen, 2017). This is why the last testing hypothesis is as follows:

H6: The membership in the single currency area (EMU) stimulates trade between exporting and importing partners.

\section{METHODOLOGY}

The analysis of the export structure was based on the data provided by the UNCTADstat, that is by the statistical database of the United Nations Conference on Trade and Development (UNCTAD 2018) for the years 1995-2015 (Maciejewski, 2017).

A gravity model is applied as the main method, using the reliable sources of data such as statistical data of Eurostat and UNCTADstat, CEPII (The Centre d'Études Prospectives et d'Informations Internationales). Instead of a core gravity model, we applied the augmented gravity model by adding such variables as "EU membership" and "EMU membership".

The analysis of the export structure of European Union countries allows referring to the differentiation in this regard at the level of individual member states. Their export structure enables to distinguish various export streams due to the intensity of the use of production factors using the SITC classification, namely (i) resource-intensive goods, (ii) labour-intensive goods, (iii) capital-intensive goods, (iv) technology-intensive goods easy to imitate, and (v) technology-intensive goods difficult to imitate (Ariff \& Hill, 1985, p. 180). This analysis was first performed for deliveries made to the market of all EU-28 countries in the years 19952015 (Table 1). 
Table 1

Goods structure of exports of EU-28 countries to the EU market taking into account the intensity of production factors in 1995 and 2015

\begin{tabular}{|c|c|c|c|c|c|c|c|c|c|c|c|c|}
\hline \multirow{2}{*}{ Country } & \multicolumn{6}{|c|}{1995} & \multicolumn{6}{|c|}{2015} \\
\hline & 1 & 2 & 3 & 4 & 5 & $\sum 1-5$ & 1 & 2 & 3 & 4 & 5 & $\sum 1-5$ \\
\hline Austria & 8.9 & 32.2 & 22.3 & 7.7 & 28.9 & 100 & 11.4 & 24.2 & 23.7 & 14.7 & 26 & 100 \\
\hline Belgium & 15.1 & 21.1 & 34.5 & 13.8 & 15.5 & 100 & 21.3 & 16.4 & 23.7 & 23.1 & 15.6 & 100 \\
\hline Bulgaria & 20.8 & 29.2 & 25.6 & 9.5 & 14.9 & 100 & 22.0 & 26.8 & 23.7 & 8.2 & 19.3 & 100 \\
\hline Croatia & 23.9 & 42.1 & 5.7 & 6.1 & 22.3 & 100 & 25.0 & 33.9 & 12.7 & 8.5 & 20.0 & 100 \\
\hline Cyprus & 28.0 & 27.8 & 35.5 & 4.2 & 4.6 & 100 & 30.6 & 4.6 & 8.9 & 30.3 & 25.6 & 100 \\
\hline Czech Republic & 15.1 & 32.9 & 23.8 & 7.4 & 20.7 & 100 & 9.1 & 21.5 & 32.1 & 15.6 & 21.7 & 100 \\
\hline Denmark & 33.4 & 26.7 & 9.0 & 11.4 & 19.4 & 100 & 30.6 & 23.3 & 10.5 & 12.3 & 23.3 & 100 \\
\hline Estonia & 29.8 & 39.2 & 10.0 & 14.1 & 7.0 & 100 & 21.7 & 27.5 & 14.5 & 18.6 & 17.7 & 100 \\
\hline Finland & 14.4 & 38.8 & 14.7 & 15.4 & 16.6 & 100 & 20.5 & 22.9 & 25.3 & 7.1 & 24.2 & 100 \\
\hline France & 16.8 & 17.2 & 31.1 & 13.7 & 21.2 & 100 & 16.2 & 15.5 & 25.9 & 14.4 & 28.0 & 100 \\
\hline Germany & 8.8 & 19.9 & 28.2 & 13.2 & 29.8 & 100 & 10.4 & 17.2 & 27.9 & 16.2 & 28.3 & 100 \\
\hline Greece & 34.8 & 39.2 & 14.8 & 3.5 & 7.7 & 100 & 44.2 & 14.4 & 19.0 & 14.2 & 8.1 & 100 \\
\hline Hungary & 25.0 & 29.1 & 15.8 & 11.1 & 19.0 & 100 & 11.1 & 13.0 & 26.5 & 17.7 & 31.7 & 100 \\
\hline Ireland & 22.8 & 18.3 & 7.4 & 41.5 & 10.0 & 100 & 15.9 & 9.0 & 8 & 53.0 & 14.1 & 100 \\
\hline Italy & 8.0 & 38.0 & 20.2 & 9.0 & 24.7 & 100 & 11.6 & 27.4 & 21.9 & 12.9 & 26.2 & 100 \\
\hline Latvia & 42.6 & 35.9 & 12.7 & 3.7 & 5.2 & 100 & 36.5 & 25.5 & 13.8 & 16.5 & 7.6 & 100 \\
\hline Lithuania & 44.2 & 31.1 & 5.8 & 8.0 & 10.9 & 100 & 44.0 & 24.4 & 9.2 & 11.9 & 10.6 & 100 \\
\hline Luxemburg & 8.6 & 30.7 & 35.5 & 12.3 & 12.9 & 100 & 12.1 & 20.3 & 39.5 & 11.5 & 16.6 & 100 \\
\hline Malta & 3.1 & 24.6 & 3.8 & 5.6 & 62.9 & 100 & 20.2 & 19.9 & 6.1 & 22.7 & 31.0 & 100 \\
\hline Netherlands & 33.5 & 15.8 & 15.6 & 20 & 15.2 & 100 & 34.2 & 12.5 & 12.6 & 26.0 & 14.8 & 100 \\
\hline Poland & 20.2 & 39.4 & 21.1 & 4.7 & 14.5 & 100 & 16.9 & 26.7 & 25.6 & 12.9 & 17.9 & 100 \\
\hline Portugal & 11.9 & 50 & 15.3 & 7.2 & 15.6 & 100 & 17.8 & 36.1 & 23.7 & 8.7 & 13.7 & 100 \\
\hline Romania & 10.3 & 56.3 & 17.5 & 4.9 & 10.9 & 100 & 10.1 & 25.1 & 29.6 & 7.1 & 28.2 & 100 \\
\hline Slovakia & 16.4 & 30.0 & 27.6 & 9.0 & 16.9 & 100 & 10.5 & 17 & 36.9 & 18.6 & 16.9 & 100 \\
\hline Slovenia & 4.9 & 39.9 & 28.3 & 6.6 & 20.2 & 100 & 12.4 & 21.6 & 34.4 & 11.0 & 20.6 & 100 \\
\hline Spain & 18.9 & 18.4 & 41.2 & 7.8 & 13.8 & 100 & 23.7 & 18.5 & 34.5 & 8.8 & 14.6 & 100 \\
\hline Sweden & 15.9 & 26.3 & 22.5 & 13.3 & 22.0 & 100 & 23.0 & 18.8 & 24.2 & 13.7 & 20.3 & 100 \\
\hline $\mathrm{UK}$ & 14.6 & 18.2 & 22.7 & 22.4 & 22.2 & 100 & 20.1 & 16.8 & 22 & 18.8 & 22.4 & 100 \\
\hline
\end{tabular}

Column 1- resource-intensive goods; Column 2 - labour-intensive goods, Column 3 - capital intensive goods; Column 4 - technology-intensive goods easy to imitate; Column 5 - technology-intensive goods difficult to imitate.

Source: on calculations based on the statistical data of UNCTAD (2018).

The data and calculations indicate a high level of variation in the intensity of the individual factors of production in the goods structure of exports of EU countries to the EU market. The export structure of the EU countries is varied, there are some countries where resource-intensive goods are predominant (Lithuania, Latvia, Netherlands), while among others the share of those goods is the smallest in exports (Czech Republic, Germany, Slovakia, Romania). The same applies to other product goods.

It seems to be appropriate to analyze the export structure of supplies to specific markets, taking into account the specificities of bilateral trade relations, which although exist within the EU's free movement of goods and factors of production, are shaped and dimensioned by individualized determinants. To confirm the need for such research, a comparative analysis of the export structure was made, due to the intensity of use of the production factors, of each of the EU-28 countries in the supply to the markets of all possible combinations of pairs of trading partners belonging to the European Union. As a result, for each of the EU countries, the structure of exports was collated and compared to 351 pairs of countries. As a tool of comparative analysis of export structures, Clark's divergence coefficient was used as a model (Clark, 1952) by the following formula: 


$$
d_{i l}=\sqrt{\frac{1}{m} \sum_{j=1}^{m}\left(\frac{q_{i j}-q_{l j}}{q_{i j}+q_{l j}}\right)^{2}}
$$

where:

$m$ - the number of goods groups specified for the analysis,

$I, l-$ the direction of export,

$j-$ particular goods groups,

$q$ - share of the goods of a given group in the export structure to the given market.

Such a coefficient takes values from 0 to 1 , with a value of zero meaning that the structures compared are identical, and a value of one means that they are completely different. Averaged over all observations (351) of the value of the coefficient in the export structure of individual EU member states in 2015 is shown in Fig. 1.

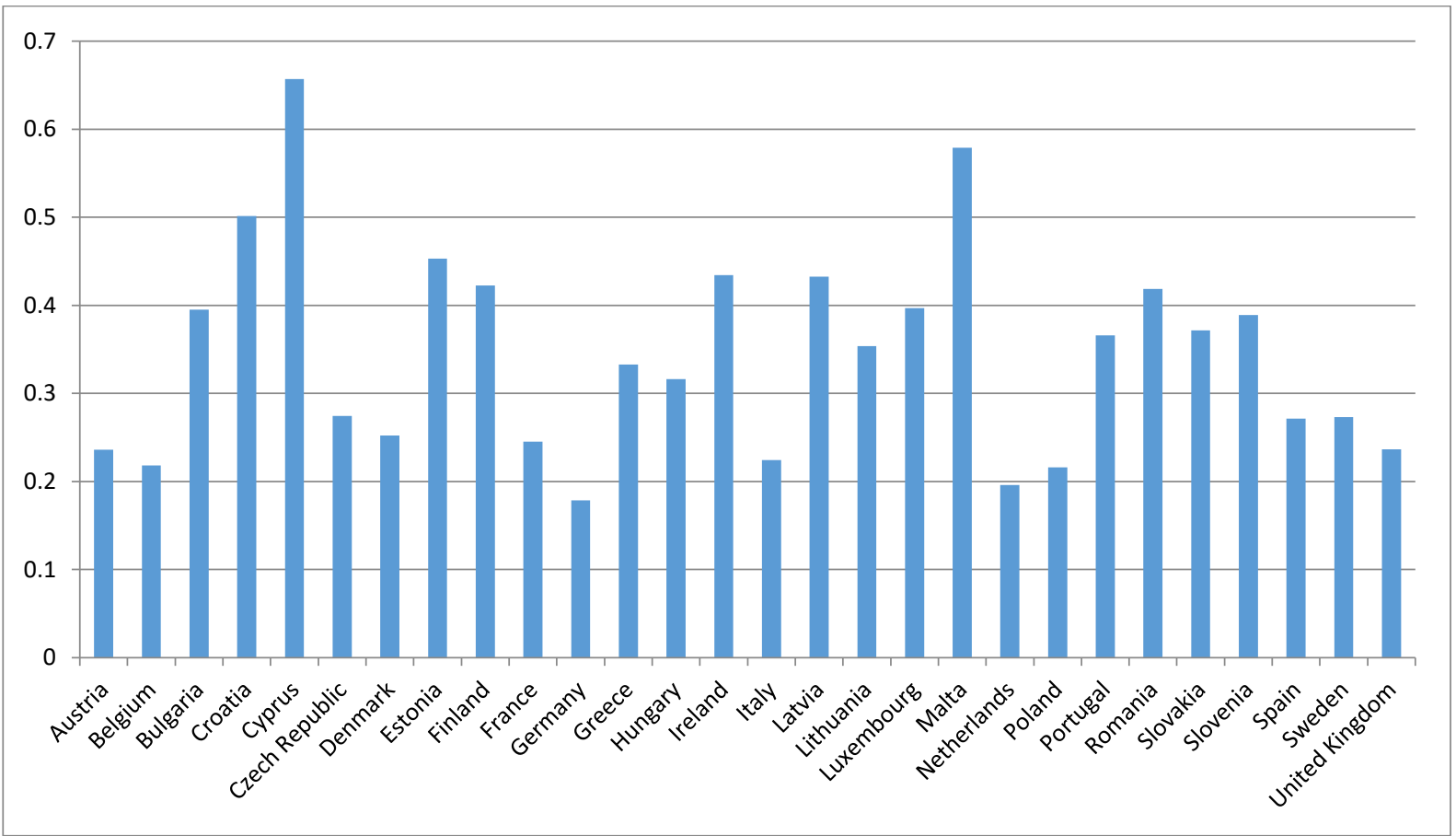

Figure 1. Average diversification of the export structure of the EU countries to the EU markets in 2015

Source: own calculations based on UNCTAD (2018)

The obtained values indicate that the intensity of the utilization of the production factors in export varies in different markets. This also applies to countries that are at similar levels of economic development, with similar resources to manufacturing factors. Therefore, the structure of their exports is limited to a limited extent by the country's wealth in selected factors. Otherwise, the structure of exports to the same markets would be similar, and the value of the divergence coefficient would be close to zero. Meanwhile, in 2015 its average level did not exceed 0.2 only in relation to the export structure of the Netherlands and Germany, and 
in Cyprus and Malta, it was even higher than 0.5. It can, therefore, be inferred that in bilateral trade relations the intensity of the use of the factors of production is influenced by other factors.

At the next stage of the study, the exports of all EU-28 countries to each other were analyzed, highlighting the structure of the goods group turnover in terms of the intensity of the use of the production factors in the years 1995-2015. During the investigated period (21 years) for each goods group, therefore, 15,876 observations were made, constituting a combination of pairs of EU-28 countries. The stationarity of the obtained time series was verified using the Dickey-Fuller test in the Gretl program (Greene, 2002).

The gravity model of international trade has been used to determine the difference in the determinants of trade between different goods groups, differing in the intensity of the use of production factors. Tinbergen (1962, pp. 263-269), referring to the gravity law of Newton, proposed that his approach to analyzing the international flows of goods was based on the assumption that the value of trade between the two countries was proportional to the result of multiplication of the income of these two counties, and hence their masses, and inversely proportional to the distance that divides them, which translates into transport costs, reducing the attractiveness of trade. In the basic version, the equation assumed the form (Tinbergen, 1962, pp. 264-265):

$$
E_{i j}=a_{0} Y_{i}^{a_{1}} Y_{j}^{a_{2}} D_{i j}^{a_{3}}
$$

or after linearization, resulting from two-sided logarithm:

$$
\log E_{i j}=a^{\prime}+a_{1} \log Y_{i}+a_{2} \log Y_{j}+a_{3} \log D_{i j}, \text { where } a^{\prime}=\log a_{0}
$$

where

$$
\begin{aligned}
& E_{i j} \text { - export from } i \text { country to } j \text { country, } \\
& Y_{i}, Y_{j}-\text { GDP of these countries, } \\
& D_{i j}-\text { the distance between these countries, } \\
& a_{0}-\text { constant, } \\
& a_{1}, a_{2} i a_{3}-\text { coefficients of proportionality. }
\end{aligned}
$$

This concept, also proposed independently by Poyhonen (1963), has become a popular model for trade modeling, mainly due to the availability of reliable data but primarily through the ability to develop equations with new variables for testing their effects on trade flows.

Gravity models are used in various social sciences to predict and describe certain behaviors that are similar to gravitational interaction as described in Isaac Newton's law of gravity. The theoretical support of the research in this field was originally very poor, however, several theoretical developments have appeared in support of the gravity model. Anderson (1979) made the first formal attempt to derive the gravity equation from a model that assumed the product differentiation. The gravity model is a major simplification when it comes to terms of dealing with the variables affecting positively on the volume of trade (GDP) and negative (distance). The core gravity model only takes into account the size of economies measured by home and host GDP (GDP per capita) and the geographical distance that is the proxy of transport costs and other barriers. However, it is debatable which measure of GDP (in current prices, in constant prices or in purchasing power parity) is the most adequate for gravity models (Wach \& Wojciechowski, 2016).

Most authors use the gravity model with an additional vector of explanatory variables. The model has the ability to be augmented by other quantitative and qualitative variables. The analysis includes a number of other variables that could potentially affect the decisions regarding the selection of the country to export (augmented gravity model). Additionally, we decided to take into account other variables expressing the 
geography (location), that is the common border. At the same time, the effects of participation in the EU, and especially in the EMU play a very important role while exporting.

The dependent variable describes the value of exports of particular categories of goods. There are also independent variables influencing the goods structure of exports (listed in Table 2 and expressed in the above discussed hypotheses):

- GDP of entities belonging to the analyzed pair of countries (GDPi, GDP $j$ ) that reflects the exporting potential of the analysed country and its importing partner (to be verified in the H1a hypothesis).

- GDP per capita of the entities belonging to the analysed pair of countries (GDPpci, GDPpc $c_{j}$ ), which refers to the level of their development (to be verified in the $H 1 b$ hypothesis).

- An indicator of the relative difference in GDP of entities belonging to the analysed pair of countries (DistGDP $P_{i j}$ ) (to be verified in the H2a hypothesis).

- An indicator of the relative difference in GDP per capita of entities belonging to the analyzed pair of countries (DistGDPpcij) (to be verified in the $H 2 b$ hypothesis).

- The distance between the analyzed pairs of countries (Distij), which is expressed in kilometers of geographical distance in a straight line between the capitals of states (to be verified in the $\mathrm{H} 3$ hypothesis).

- Having by a pair of countries of the common border (BORD $D_{\mathrm{ij}}$ ) (to be verified in the $H 4$ hypothesis).

- The membership in the European Union of both exporting and importing partners belonging to the analysed pair of countries ( $E U_{i j}$ ) (to be verified in the $H 5$ hypothesis).

- The membership in the European Monetary Union of both exporting and importing partners belonging to the analysed pair of countries (Euro ij) (to be verified in the H6 hypothesis).

Against the background of its increased popularity and data availability, a range of commonly made econometric mistakes have recently been discussed in the literature, mostly pertaining to the (omitted) characteristics of countries or country pairs in gravity models. Some authors show that there is indeed a problem with the non-stationarity of variables commonly used in gravity equations (Zwinkels \& Beugelsdijk, 2010).

The gathered observations of the export value and the variables determining its level for the pairs of EU-28 countries in the period 1995-2015 constitute a set of time-crossing data. The classical least squares (CLS) method for evaluating the significance of the interaction of individual independent variables can be used when there are no individual effects specific to individual pairs of countries that cannot be explained solely by the magnitude of the effects observed for observing independent variables and when there is no change in the analysed phenomenon over time. At that time, values for the analysis are treated as crosssectional data (Honore, Luoija, 2004). However, it can be assumed that the relationship between individual pairs of countries is affected by factors specific to individual couples. To account for this aspect, the analysis was performed on panel data, creating for each pair of countries a group with a number of observations corresponding to the length of the research period, which covered 21 years. As a result, 756 groups were made, representing a combined pair of EU-28 countries, and 21 observations in each of them (a total of 15,876 observations). 
Table 2

List of variables used in the study

\begin{tabular}{|c|c|c|c|c|c|}
\hline $\begin{array}{l}\text { Type of } \\
\text { variable }\end{array}$ & Variable & $\begin{array}{l}\text { Expected } \\
\text { impact }\end{array}$ & Description & Unit & Source \\
\hline $\begin{array}{l}\text { Dependent } \\
\text { variable }\end{array}$ & $E_{i j, t}$ & & $\begin{array}{l}\text { Value of export of particular } \\
\text { categories of goods from i-EU' } \\
\text { country to j-EU-28 country in t- } \\
\text { period }\end{array}$ & millions of USD & UNCTADstat \\
\hline \multirow{5}{*}{$\begin{array}{l}\text { Core gravity } \\
\text { model } \\
\text { variables }\end{array}$} & $G D P_{i, t}$ & $(+)$ & $\begin{array}{l}\text { nominal GDP in i-EU' country } \\
\text { in t-period }\end{array}$ & millions of USD & UNCTADstat \\
\hline & $G D P_{j t}$ & $(+)$ & $\begin{array}{l}\text { nominal GDP in } j \text {-EU' country } \\
\text { in t-period }\end{array}$ & millions of USD & UNCTADstat \\
\hline & $G D P p c_{j, t}$ & $(+)$ & $\begin{array}{l}\text { nominal GDP per capita in } i \text {-EU' } \\
\text { country within EU-28 in } \mathrm{t}- \\
\text { period }\end{array}$ & millions of USD & UNCTADstat \\
\hline & $G D P p c_{j, t}$ & $(+)$ & $\begin{array}{l}\text { nominal GDP per capita in j-EU' } \\
\text { country within EU-28 in } \mathrm{t}- \\
\text { period }\end{array}$ & millions of USD & UNCTADstat \\
\hline & $D I S T_{i j}$ & $(-)$ & $\begin{array}{l}\text { geographical distance between } \\
\text { capitals of } i \text {-EU' country and } j \text { - } \\
\text { EU country within EU-28 }\end{array}$ & $\mathrm{Km}$ & CEPII database \\
\hline \multirow[t]{2}{*}{$\begin{array}{l}\text { Augmented } \\
\text { variables }\end{array}$} & $\operatorname{DistGDP}_{i j}$ & $(-)$ & $\begin{array}{l}\text { the relative difference in GDP } \\
\text { of entities belonging to the } \\
\text { analysed pair of countries }\end{array}$ & indicator $[0 ; 1]$ & UNCTADstat \\
\hline & DistGDPpcij & $(-)$ & $\begin{array}{l}\text { the relative difference in GDP } \\
\text { per capita of entities belonging } \\
\text { to the analysed pair of countries }\end{array}$ & indicator $[0 ; 1]$ & UNCTADstat \\
\hline $\begin{array}{l}\text { Location } \\
\text { variables }\end{array}$ & $B O R D_{i j}$ & $(+)$ & $\begin{array}{l}\text { common border between } i \text {-EU' } \\
\text { country and } j \text {-EU country }\end{array}$ & dummy & CEPII database \\
\hline \multirow[t]{2}{*}{ Membership } & $E U_{i j, t}$ & $(+)$ & $\begin{array}{l}\text { binary variable: } 1 \text { if } i \text {-EU' } \\
\text { country and } j \text {-EU country in } \mathrm{t}- \\
\text { period were both in EU, } 0 \\
\text { others }\end{array}$ & dummy & CEPII database \\
\hline & Euro $_{i j, t}$ & $(+)$ & $\begin{array}{l}\text { binary variable: } 1 \text { if } i \text {-EU' } \\
\text { country and } j \text {-EU country in } \mathrm{t}- \\
\text { period were both in EMU, } 0 \\
\text { others }\end{array}$ & dummy & CEPII database \\
\hline
\end{tabular}

Source: own study based on UNCTADstat (2018) and CEPII (2017).

The study thus assumes the following linearized form of the gravity model:

$$
\begin{gathered}
\ln E_{i j t}=a_{o}+a_{1} \ln G D P_{i t}+a_{2} \ln G D P_{j t}+a_{3} \ln G D P p c_{i t} \\
+a_{4} \ln G D P p c_{j t}+a_{5} \ln D i s t G D P_{i j t}+a_{6} \ln D i s t G D P p c_{i j t}+a_{7} \ln D i s t_{i j t} \\
+a_{8} B O R D_{i j t}+a_{9} E U_{i j t}+a_{10} \text { Euro }_{i j t}+\varepsilon_{i j t}
\end{gathered}
$$

where

$E-$ export of $i$ country to $j$ country,

$a_{0}-$ constant,

$a_{1}, \ldots, a_{10}-$ structural parameters of the model for the above-mentioned variables,

$\varepsilon$ - random element, $t=1, \ldots, 21$. 


\section{EMPIRICAL RESULTS AND DISCUSSION}

The regression analysis for the panel data can be performed assuming there are no individual effects (pooled model), assuming also the homogeneity of all analyzed objects. However, because in practice this assumption is difficult to achieve, two other basic approaches (Bell \& Jones, 2015) are used to estimate the parameters of a model based on the panel data. The first is a fixed effects estimator (FE), which assumes that the individual effects for individual units are not accidental and can be estimated and therefore accounted for the difference in the free expression. The second way is to use the random effects estimator (RE), which treats individual effects as random variables and they are a part of the random component.

Calculations were made by using the Gretl statistical software, estimating the parameters of the model separately for the export streams of each, distinguished by the intensity of utilization of the production factors, the goods group (Maciejewski, 2017). The statistically insignificant variables were removed from the model and then the estimation of the parameters was repeated. In the first place, the pooled model was estimated using the classical least squares (CLS) method. The results are shown in Table 3.

Table 3

Results of estimation of the pooled model parameters

\begin{tabular}{|c|c|c|c|c|c|c|c|}
\hline & Variable & Parameter & 1 & 2 & 3 & 4 & 5 \\
\hline consta & & $a_{0}$ & $-2.247 * * *$ & $-3.375^{* * * *}$ & $-3.682 * * *$ & $-5.649 * * *$ & $-5.976 * * *$ \\
\hline H1a & $G D P_{i}$ & $a_{1}$ & $0.836^{* * *}$ & $0.885^{* * *}$ & $0.971 * * *$ & $0.840 * * *$ & $0.961 * * *$ \\
\hline & GDPj & $a_{2}$ & $0.674 * * *$ & $0.788^{* * *}$ & $0.754 * * *$ & $0.715^{* * *}$ & $0.737 * * *$ \\
\hline$H 1 b$ & $G D P p c_{i}$ & $a_{3}$ & $-0.352 * * *$ & $-0.244 * * *$ & $-0.198 * * *$ & $0.107 * * *$ & $-0.070^{* * *}$ \\
\hline & GDPpcj & $a_{4}$ & $-0.188^{* * *}$ & $-0.235 * * *$ & $-0.308 * * *$ & $-0.365^{* * *}$ & $-0.197 * * *$ \\
\hline $\mathrm{H} 2 a$ & $\operatorname{DistGDP}_{i j}$ & $a_{5}$ & $-0.013 * * *$ & - & $-0.040 * * *$ & $-0.308 * * *$ & $-0.017 * * *$ \\
\hline$H 2 b$ & $D_{i s t G D P p c_{i j}}$ & $a_{6}$ & $-0.084 * * *$ & $-0.022 * * *$ & $-0.029 * * *$ & $-0.086^{* * *}$ & $-0.040 * * *$ \\
\hline H3 & Dist $_{i j}$ & $a_{7}$ & $-1.031 * * *$ & $-1.105^{* * *}$ & $-1.163^{* * *}$ & $-1.013^{* * *}$ & $-1.087 * * *$ \\
\hline H4 & $B O R D_{i j}$ & $a_{8}$ & $1.103^{* * *}$ & $0.712^{* * *}$ & $0.756^{* * *}$ & $0.456 * * *$ & $0.499 * * *$ \\
\hline H5 & $E U_{i j}$ & $a_{9}$ & $0.444^{* * *}$ & $0.185^{* * *}$ & $0.379 * * *$ & $0.379 * * *$ & $0.050^{* *}$ \\
\hline H6 & Euro $_{i j}$ & $a_{10}$ & $0.110^{* * *}$ & $-0.046 * * *$ & $0.065^{* * *}$ & - & $-0,122 * * *$ \\
\hline & $\mathrm{R}^{2}$ & & 0.794 & 0.862 & 0.849 & 0.812 & 0.851 \\
\hline
\end{tabular}

Statistical significance at ${ }^{*} \mathrm{p}<0.1 ;{ }^{* *} \mathrm{p}<0.05 ;{ }^{* * *} \mathrm{p}<0.01$.

Column 1 - resource-intensive goods; Column 2 - labour-intensive goods, Column 3 - capital intensive goods; Column 4 - technology-intensive goods easy to imitate; Column 5 - technology-intensive goods difficult to imitate.

Factors that were not statistically significant were removed from the model.

Source: own calculations based on the data of (UNCTAD 2018) and (EUROSTAT 2018).

Diagnostic tests were then performed to determine whether the panel model could be estimated using CLS method, or whether individual effects for individual pairs of countries were used for the fixed effects (FE) or random effects (FE) estimators. The merit of using the CLS method instead of the FE estimator is determined by the test of the combined significance of group mean inequality (Wald test). The Breusch-Pagan test allows us to determine whether the CLS method gives better results than the RE estimator (Zaman, 2000). For all categories of goods, the results of the tests indicated the need to reject the assumption that the CLS method-based pooled model was correct for the significance of fixed and random effects. For the choice between the FE and RE estimators, Hausman's test is used to examine the correlation between explanatory variables and random effects. Hausmann's test results for all goods groups have shown the superiority of the FE effect estimator. The results obtained using the FE estimator are given in Table 4. 
It is necessary to omit in the model the variables whose values are constant over time for each pair of countries, what is research limitation of the analysis using the fixed effects estimator (Folfas, 2011). Our analysis such a constraint concerns two key variables for gravity models such as a geographic distance and common boundaries. In this situation, the random effects estimator $(\mathrm{RE})$ is an alternative but requires an additional assumption that the explanatory variables with individual effects are not correlated. This assumption was not fulfilled. It is also possible to use dynamic panel models in which explanatory variables are replaced by instruments that are variable levels, delayed by two or more periods. The results of the panel dynamic model estimation are presented in Table 5.

Table 4

Estimation of model parameters using the FE estimator

\begin{tabular}{|c|c|c|c|c|c|c|c|}
\hline & Variable & Parameter & 1 & 2 & 3 & 4 & 5 \\
\hline \multicolumn{2}{|c|}{ constant } & $a_{0}$ & $-8.596 * * *$ & $-2.975^{* * *}$ & $-4.849 * * *$ & $-5.086 * * *$ & $-5.451 * * *$ \\
\hline \multirow[t]{2}{*}{ H1a } & $G D P_{i}$ & $a_{1}$ & $0.748^{* * *}$ & $0.752^{* * *}$ & $0.864 * * *$ & $0.792 * * *$ & $0.874 * * *$ \\
\hline & GDPj & $a_{2}$ & $0.704 * * *$ & $0.747 * * *$ & $0.672^{* * *}$ & $0.715^{* * *}$ & $0.681^{* * *}$ \\
\hline \multirow[t]{2}{*}{ H1b } & $G D P p c_{i}$ & $a_{3}$ & $1.499 * * *$ & $2.939 * * *$ & $2.192^{* * *}$ & $1.475^{* * *}$ & $-2.130 * * *$ \\
\hline & GDPpcj & $a_{4}$ & $-0.570 * * *$ & $0.401 * * *$ & $0.661 * * *$ & $0.837 * * *$ & $1.037 * * *$ \\
\hline$H 2 a$ & $D_{i s t G D P_{i j}}$ & $a_{5}$ & - & - & $-0.049 * * *$ & $-0.018^{* *}$ & $-0.041 * * *$ \\
\hline$H 2 b$ & DistGDPpcij & $a_{6}$ & - & - & - & $-0.026 * * *$ & - \\
\hline H3 & Dist $_{i j}$ & $a_{7}$ & - & - & - & - & - \\
\hline$H 4$ & $B_{O R D_{i j}}$ & $a_{8}$ & - & - & - & - & - \\
\hline H5 & $E U_{i j}$ & $a_{9}$ & $0.121^{* * *}$ & - & $0.209 * * *$ & $0.376^{* * *}$ & $0.038^{* *}$ \\
\hline H6 & Euro $_{i j}$ & $a_{10}$ & $0.125^{* * *}$ & $-0.046 * * *$ & $-0.031 * *$ & $0.199 * * *$ & - \\
\hline \multicolumn{3}{|c|}{ Inter-group $\mathrm{R}^{2}$} & 0.961 & 0.966 & 0.966 & 0.947 & 0.960 \\
\hline \multicolumn{3}{|c|}{ Intra-group $\mathrm{R}^{2}$} & 0.585 & 0.556 & 0.605 & 0.577 & 0.577 \\
\hline
\end{tabular}

Statistical significance at $* \mathrm{p}<0.1 ; * * \mathrm{p}<0.05 ; * * * \mathrm{p}<0.01$.

Column 1 - resource-intensive goods; Column 2 - labor intensive goods, Column 3 - capital intensive goods; Column 4 - technology-intensive goods easy to imitate; Column 5 - technology-intensive goods difficult to imitate.

Factors that were not statistically significant were removed from the model.

Source: own calculations based on the data of (UNCTAD 2018) and (EUROSTAT 2018).

Results of estimation of dynamic model parameters

\begin{tabular}{|c|c|c|c|c|c|c|c|}
\hline & Variable & Parameter & 1 & 2 & 3 & 4 & 5 \\
\hline \multicolumn{2}{|c|}{ constant } & $a_{0}$ & $-1.340^{* * *}$ & $-3.151 * * *$ & $-1.688^{* * *}$ & -0.586 *** & $-2.972 * * *$ \\
\hline \multirow[t]{2}{*}{ H1a } & $G D P_{i}$ & $a_{1}$ & $0.472 * * *$ & $0.912^{* * *}$ & $0.493^{* * *}$ & $0.171 * * *$ & $0.553 * * *$ \\
\hline & GDPj & $a_{2}$ & $0.382^{* * *}$ & $0.810^{* * *}$ & $0.383^{* * *}$ & $0.149^{* * *}$ & $0.425^{* * *}$ \\
\hline \multirow[t]{2}{*}{ H1b } & $G D P p c_{i}$ & $a_{3}$ & $-0.195^{* * *}$ & $-0.268^{* * *}$ & $-0.107 * * *$ & - & $-0.063^{* * *}$ \\
\hline & GDPpcj & $a_{4}$ & $-0.094 * * *$ & $-0.257 * * *$ & $-0.162 * * *$ & $-0.099 * * *$ & $-0.131 * * *$ \\
\hline$H 2 a$ & $D_{i s t G D P_{i j}}$ & $a_{5}$ & - & - & $-0.591 * * *$ & $-0.007^{*}$ & - \\
\hline$H 2 b$ & DistGDPpcij & $a_{6}$ & $-0.040 * * *$ & $-0.023^{*}$ & - & $-0.012 * * *$ & $-0.020 * * *$ \\
\hline H3 & Dist $_{i j}$ & $a_{7}$ & $-0.589 * * *$ & $-1.136^{* * *}$ & $-1.163^{* * *}$ & $-0.216 * * *$ & $-0.631 * * *$ \\
\hline$H 4$ & $B O R D_{i j}$ & $a_{8}$ & $0.628^{* * *}$ & $0.724 * * *$ & $0.397 * * *$ & $0.082^{* * *}$ & $0.277 * * *$ \\
\hline H5 & $E U_{i j}$ & $a_{9}$ & $0.236^{* * *}$ & $0.095^{* *}$ & $0.145^{* * *}$ & $0.098^{* * *}$ & - \\
\hline H6 & Euro $_{i j}$ & $a_{10}$ & $0.073^{* *}$ & - & - & - & $-0.069 * * *$ \\
\hline
\end{tabular}

Statistical significance at $* \mathrm{p}<0.1 ; * * \mathrm{p}<0.05 ; * * * \mathrm{p}<0.01$.

Column 1- resource-intensive goods; Column 2 - labour-intensive goods, Column 3 - capital intensive goods; Column 4 - technology-intensive goods easy to imitate; Column 5 - technology-intensive goods difficult to imitate.

Factors that were not statistically significant were removed from the model.

Source: own calculations based on the data of (UNCTAD 2018) and (EUROSTAT 2018). 
The verifying of the assumed hypotheses (H1-H6) was done the base of the gravity model and statistical calculations and results presented in Tables 3-5. The results of the estimation of the described methods give a consistent result on the direction of GDP changes of the exporter's country and its partner on the export of the distinctive components of its goods structure. A positive correlation between the size of economies and the value of trade between them was confirmed. It was found that the impact of these factors was not the same for goods based on the use of various factors of production. The results of the estimation of the dynamic model illustrate particularly strongly this diversity, which reveals that the larger is the size of the economies participating in the exchange is, the smaller is the export of labourintensive goods.

The estimation of the parameters determining the direction and the force of the impact of GDP per capita changes on trade did not give unambiguous answers. The FE estimator shows a positive effect of GDP per capita of the exporting country on the value of turnover. However, this does not apply to technology-intensive goods difficult to imitate, which can be explained by the fact that, on one hand, because of increasing the productivity of these products, they are sold on non-EU markets, and on the other hand, changes in consumer preferences in the market of the exporting country lead to the absorption of these products in the local market. The high level of economic development is also conducive, particularly in the context of the single market, to shifting production factors whose migration may be an alternative to trade. On the other hand, the growing GDP per capita of a partner country results into an increase in the supply of all categories of goods, excluding resource-intensive goods, to the market, which can also be explained by a change in consumer preferences, which, along with progressive economic development, are turning towards technologically advanced goods. This finds the acknowledgment at the highest value of the parameter specifying the interaction of this particular variable. Parameters estimated in pooled and dynamic models accept lower values and confirm the direction of the impact of GDP per capita changes on exports only in those cases where the negative relationship was previously identified.

The geographic distance sharing partners measured by the GDP gap and GDP per capita, in cases where it turned out to be statistically significant, was expected to be negatively correlated with the value of exports, as expected. This confirms the assumptions of the theory of similarity of preferences for increasing turnover between economies in similar stages of development.

The geographical factor has turned out to be an important determinant of trade turnover. With varying intensity, but for all goods categories, the distance between partners was a barrier to the increase in turnovers (especially for capital-intensive goods), while having a common boundary facilitated the intensification of trade (mainly resource- and labor-intensive goods).

The membership of both trading partners in the EU has also been statistically significant and conducive to the increase in trade. In this respect, however, membership in the euro area was often less relevant (statistically insignificant), and in the case of technology-intensive goods difficult to imitate (hightech products), it was correlated negatively with the value of exports, which could be found in the attractiveness of alternative to trade the migration of production factors in the euro area.

\section{CONCLUSION}

The results obtained in this study are in line with the prior results of other researchers from different corners of our globe. Stojčić, Vojinić and Aralica (2018) proved that trade liberalization in the EU increased the quality of exports and the share of high technology intensive industries in its structure across all new member states, similarity we observed a positive impact of the EU on international trade. Kumar and Ahmed (2015) found that the South Asia Free Trade Agreement (SAFTA) produced trade creation among 
its members, and this study similarly proves that the EU as the integrating grouping has a stimulating impact on international trade. Cieślik, Michałek and Mycielski (2012) found that the adoption of the euro results in trade expansion for the CEE countries. Similarly, our results prove the positive impact of euro on international trade. In some cases the results needs to be looked into very carefully. The situation in the European Union (small versus large member states) seems to be a bit similar to the situation of Canada (small and large provinces) and this is why the results in some points are ambiguous, which means there is much to be learned from attempting to explain the variation (Agnosteva et al., 2019).

The conducted analysis of data showed that the structure of exports of EU countries taking into account the goods groups due to its intensity of use of production factors is highly diverse. This applies not only to countries at different levels of economic development but also to those with similar levels and having similar resources of production. In spite of the functioning of the Single European market, the free movement of goods, services, capital and labour, such factors (being crucial in the design of gravity-based foreign trade models) remain essential for the attractiveness of commercial co-operation as (i) the size and level of economic partners, (ii) the geographical distance or (iii) the common border (Table 6). Their importance results in the unequal distribution of trade in products differing in the intensity of use of different production factors.

Table 6

Verification of research hypotheses

\begin{tabular}{|l|l|l|}
\hline No. & Hypotheses & Status \\
\hline H1a: & $\begin{array}{l}\text { The higher GDP, both of the exporting country and of the importing country (as its } \\
\text { partner), should, therefore, be conducive to an increase in the value of the trade. }\end{array}$ & confirmed \\
\hline H1b: & $\begin{array}{l}\text { The higher levels of GDP per capita of both exporting and importing partners foster an } \\
\text { increase in the value of the trade. }\end{array}$ & ---- \\
\hline H2a: & $\begin{array}{l}\text { The lower the indicator of the relative difference in the value of GDP of entitles belonging } \\
\text { to the analyzed pair of countries, especially in bigger economies, the larger the volume in } \\
\text { trade between these countries. }\end{array}$ & confirmed \\
\hline H2b: & $\begin{array}{l}\text { Leveling the GDP per capita of trading partners cause the increase of the value of their } \\
\text { trade. }\end{array}$ & confirmed \\
\hline H3: & $\begin{array}{l}\text { The closer the geographic distance of the exporting and the importing partners, the } \\
\text { intensity of trade is higher. }\end{array}$ & confirmed \\
\hline H4: & $\begin{array}{l}\text { Having a common border between the exporting and importing partners stimulate the } \\
\text { value of the trade. }\end{array}$ & confirmed \\
\hline H5: & $\begin{array}{l}\text { The membership in the EU as the integration grouping stimulates trade between exporting } \\
\text { and importing partners. }\end{array}$ & confirmed \\
\hline H6: & $\begin{array}{l}\text { The membership in the single currency area (EMU) stimulates trade between exporting } \\
\text { and importing partners. }\end{array}$ & $\begin{array}{l}\text { only dynamic } \\
\text { model }\end{array}$ \\
\hline
\end{tabular}

Source: own study.

It is also worth noting that there are a number of obtained results deviated from the theoretical assumptions of the gravity model, whose explanation might lie in the integration of European markets. Creating beneficial conditions for the flow of production factors can create other flows alternative to trade, particularly of these factors, which are characterized by a high level of mobility, such as capital and technology.

There are some obvious implications of the empirical results presented in this study. To intensify both the value and volume of international trade in a given economy, the policy makers should focus on trading partners of the similar relative wealth within a short geographical distance. Policy makers should be very cautious and cool down any populistic voices on nationalism and the separation from the EU as it would 
certainly decrease the value of international trade, as it was showed in the results in this article and by many other researchers.

The research method adopted in the study has a number of limitations, which does not allow uncritically to accept the obtained results. "The gravity model has become the 'workhorse' baseline model for estimating the effects of international integration, this has important empirical implications. In particular, we show that, unless heterogeneity is accounted for correctly, gravity models can greatly overestimate the effects of integration on the volume of trade" (Cheng \& Wall, 2004). The application and the line of reasoning is primarily based on a comparative analysis of export goods structures, but ignores other aspects of the internal determinants of the functioning of the economies or firms operating within them. This is the direction for further research, which should focus on selected factors of production.

Of course, there is a need to conduct further empirical investigations into this research problem. It would be good to enrich the augmented gravity model of new variables such as the financial distance measured by the integration degree of financial markets; the measures of transport performance (like transportation cost, shipment delays, supply chain logistics), or cultural distance.

\section{ACKNOWLEDGEMENT}

This article is financed from the funds allocated to the Faculty of Economics and International Relations of Cracow University of Economics in the framework of grants for maintaining research potential.

\section{REFERENCES}

Agnosteva, D.E., Anderson, J.E., Yotov, Y.V., (2019). Intra-national trade costs: Assaying regional frictions. European Economic Review, 112(1), 32-50.

Ambroziak, L. (2017). Decomposition of Poland's Bilateral Trade Imbalances by Value Added Content. Entrepreneurial Business and Economics Review, 5(2), 51-69. https://doi.org/10.15678/EBER.2017.050203

Anderson, J.E. (1979). A Theoretical Foundation for the Gravity Equation. The American Economic Review, 69(1), 106116.

Ariff, M., \& Hill, H. (1985). Export-Oriented Industrialisation: The ASEAN Experience. London - New York: Routledge Taylor and Francis Group.

Baltagi, B.H. (2005). Econometric Analysis of Panel Data. Chichester: Wiley \& Sons.

Basile, R., Parteka, A., \& Pittiglio R. (2018). Export diversification and economic development: a dynamic spatial data analysis. Review of International Economics, 26(3), 634-650. https://doi.org/10.1111/roie.12316

Bell, A., \& Jones, K. (2015). Explaining Fixed Effects: Random Effects Modeling of Time-Series Cross-Sectional and Panel Data. Political Science Research and Methods, 3(1), 133-153.

Bittmannova, B. (2016). Trade creation and trade diversion in the European Union after creation of Single Market. Journal of Applied Economic Sciences, 11(6), 1176-1184.

Brodzicki T., \& Kwiatkowski, J. (2018). An Empirical Investigation into the Role of Technology Gap in the Trade Relations of the EU Member States. Entrepreneurial Business and Economics Review, 6(2), 111-135. https://doi.org/10.15678/EBER.2018.060206

Brun, J.F., Carrere, C., Guillaumont, P., \& Melo, J. (2005). Has Distance Died? Evidence from a Panel Gravity Model. The World Bank Economic Review, 3(15), 5-16.

Cairncross, F. (2001). The death of distance: How the communications revolution is changing our lives. Boston: Harvard Business School Press.

Chaney, T. (2018). The Gravity Equation in International Trade: An Explanation. Journal of Political Economy, 126(1), 150-177.

Cheng, I.H., \& Wall, H.J. (2004). Controlling for Heterogenity in Gravity Models of Trade and Integration. The Federal Reserve Bank of St. Louis Working Paper Series.: http:/ / research.stlouisfed.org/ wp/1999/1999-010.pdf 
Cieślik, A. (2005). Intraindustry Trade and Relative Factor Endowments. Review of International Economics, $13(5), 904$ 926. https://doi.org/10.1111/j.1467-9396.2005.00544.x

Cieślik, A., Michałek, J.J., Mycielski, J. (2012). Measuring the trade effects of the euro in Central and Eastern Europe. Journal of International Trade \& Economic Development, 12(1), 25-49. https://doi.org/10.1080/09638199.2012.642527

Clark, J.P. (1952). An Extension of the Coefficient of Divergence for Use with Multiple Characters. Copeia, 2, 61-64. DOI: $10.2307 / 1438532$

Clark, X., Dollar D., \& Micco, A. (2004). Port efficiency, maritime transport costs, and bilateral trade. Journal of Development Economics, 75(2), 417-450.

Duarte, R., Pinilla, V., \& Serrano, A. (2018). Factors driving embodied carbon in international trade: a multiregional input-output gravity model. Economic Systems Research, 30(4), 545-566. https://doi.org/10.1080/09535314.2018.1450226

Elmslie, B. (2018). Retrospectives: Adam Smith's Discovery of Trade Gravity. Journal of Economic Perspectives, 32 (2): 209-22. DOI: $10.1257 /$ jep.32.2.209

EUROSTAT (2018). Distance calculator. Retrieved from http://ec.europa.eu/programmes/erasmusplus/resources/distance-calculator (accessed: 15 June 2018).

Felipe, J. \& Kumar, U. (2010). The Role of Trade Facilitation in Central Asia: A Gravity Model. Asian Development Bank Working Paper No. 628.

Fitzsimons, E., Hogan, F., \& Neary, J.P. (2013). Explaining the Volume of North-South Trade in Ireland: A Gravity Model Approach. The Economic and Social Review, 30(4), 381-401.

Folfas, P. (2011). FDI between EU member states: gravity model and corporate taxes. Conference Proceedings of 13th Annual ETSG 2011 Conference, Copenhagen, 8-10 September 2011. Copenhagen Business School and University of Copenhagen. Retrieved from (access: 15 November 2018).

Frankel, J. \& Rose, A. (2002). An estimate of the effect of common currencies on trade and income. Quarterly Journal of Economics, CXVII(2), 437-466

Ghemawat, P. (2001). Distance still matters: The hard reality of global expansion. Harvard Business Review, 79(8), 137147.

Greene, W. H. (2002). Econometric Analysis. New Jersey: Prentice Hall.

Honoré, B.E., \& Luojia H. (2004). Estimation of Cross Sectional and Panel Data Censored Regression Models with Endogeneity. Journal of Econometrics, 122(2), 293-316.

Johnson, H.G. (1959). Economic development and international trade. Nationalokonomisk Tidsskriff, 1, 327-377.

Johnson, H.G. (1968). Factor Endowments, International Trade and Factor Prices. In R.E. Caves \& H.G. Johnson, Readings in International Economics. Homewood, Ill.: Irwin, 78-89.

Kepaptsoglou, K., Karlaftis, M., \& Tramboulas, D. (2010). The Gravity Model Specification for Modeling International Trade Flows and Free Trade Agreement Effects: A 10-Year Review of Empirical Studies. The Open Economics Journal, 3: 1-13.

Kumar, S., \& Ahmed, S. (2015). Gravity Model by Panel Data Approach: An Empirical Application with Implications for South Asian Countries. Foreign Trade Review, 50(4), 233-249. https://doi.org/10.1177/0015732515598587

Linder, S.B. (1961). An Essay on Trade and Transformation. Almqvist \& Wiksells Boktrycketi AB, Uppsala. Retrieved from: https://ex.hhs.se/dissertations/221624-FULLTEXT01.pdf (access: 15 November 2018).

Linneman, H. (1966). An Econometric Study of International Trade Flows, Amsterdam: North Holland Publishing.

Maciejewski, M. (2017). Determinanty wykorzystania czynników wytwórczych w strukturze eksportu państw Unii Europejskiej. Horyzonty Polityki, 8(22), 131-149. DOI: 10.17399/HP.2017.082207

Martinez- Zarzoso, I., \& Nowak-Lehmann, F. (2002). Augmented Gravity Model: An empirical application to Mercosur-European Union trade flows. Journal of Applied Economics, 6(2), 291-316.

Martínez-Zarzoso, I., \& Johannsen, F. (2017). Euro Effect on Trade in Final, Intermediate and Capital Goods. International Journal of Finance and Economics, 22(1), 30-43. DOI: 10.1002/ijfe.1567

Morawczyński, R., \& Wach, K. (2004). Does Polish foreign trade impact employment? An empirical investigation (pp. 55-66). In J. Targalski (ed.), Entrepreneurship, employment and beyond 2003. Kraków: Cracow University of Economics. 
Ohlin, B. (1933). Interregional and International Trade. Cambridge, MA: Harvard University Press.

Poyhonen, P. (1963). A tentative model for the volume of trade between countries. Weltwirtschaftliches Archiv, 90(1), 93100.

Rybczynski, T.M. (1955). Factor endowments and relative commodity prices. Economica, 22, 336-341.

Samuelson, P.A. (1948). International trade and the equalisation of factor prices. Economic Journal, 58, 163-184.

Samuelson, P.A. (1949). International factor price equalisation once again. Economic Journal, 59, 181-196.

Sapkota, J.B., Acharya, C.P., Minowa, M., \& Neupane, P. (2018). Trade integration in Asia: Trends and determinants. Journal of International Studies, 11(3), 271-283. doi: 10.14254/2071-8330.2018/11-3/21

Shin, Y. \& Serlenga L. (2004). Gravity Models of the Intra-EU Trade: Application of the Hausman-Taylor Estimation in Heterogeneous Panels with Common Time-specific Factors. University of Edinburgh, Edinburgh. Retrieved from: http://www.econ.ed.ac.uk/papers/id105_esedps.pdf (accessed: 14 July 2018).

Somma, E. (1994). Intra-industry trade in the European computers industry. Weltwirtschaftliches Archiv, 130(4), $784-799$.

Stojčić, N., Vojinić, P., \& Aralica, Z. (2018). Trade liberalization and export transformation in new EU member states. Structural Change and Economic Dynamics, 47, 114-126.

Stolper, W., \& Samuelson, P. (1941). Protection and real wages. Review of Economic Studies, 9, 58-73.

Tinbergen, J. (1962). Shaping the World Economy; Suggestions for an International Economic Policy. Twentieth Century Fund, New York. Retrieved from: http://hdl.handle.net/1765/16826 (accessed: 1 July 2018).

Tung, L.T. (2018). Impact of remittance inflows on trade balance in developing countries. Economics and Sociology, 11(4), 80-95. doi: 10.14254/2071-789X.2018/11-4/5

UNCTAD (2018). UNCTADstat. Retrieved from: http://unctadstat.unctad.org (accessed: 15 January 2018).

van Bergeijk, P.A.G, \& Brakman, S. (2014). Introduction: The comeback of the gravity model. In P.A.G van Bergeijk \& S. Brakman (Eds.), The Gravity Model in International Trade: Advances and Applications. Cambridge: Cambridge University Press.

van Marrewijk, C. (2017). International Trade. Oxford: Oxford University Press.

Wach, K. (2015). Entrepreneurship without Borders: Do Borders Matter for International Entrepreneurship. Problemy Zarzquarania, 13(1[2]), 82-92.

Wach, K., \& Wojciechowski, L. (2016). Determinants of inward FDI into Visegrad countries: empirical evidence based on panel data for the years 2000-2012. Economics and Business Review, 2(1), 34-52. DOI: 10.18559/ebr.2016.1.3

Yasar, M., \& Morrison Paul C.J. (2008). Foreign Technology Transfer and Productivity: Evidence from a Matched Sample. Journal of Business \& Economic Statistics, 26(1), 105-112.

Zaman, A. (2000). The Inconsistency of the Breusch-Pagan Test. Journal of Economic and Social Research, 2(1), 1-11.

Zwinkels, R.C.J., \& Beugelsdijk, S. (2010). Gravity equations: Workhorse or Trojan horse in explaining trade and FDI patterns across time and space?. International Business Review, 19(1), 102-115. 